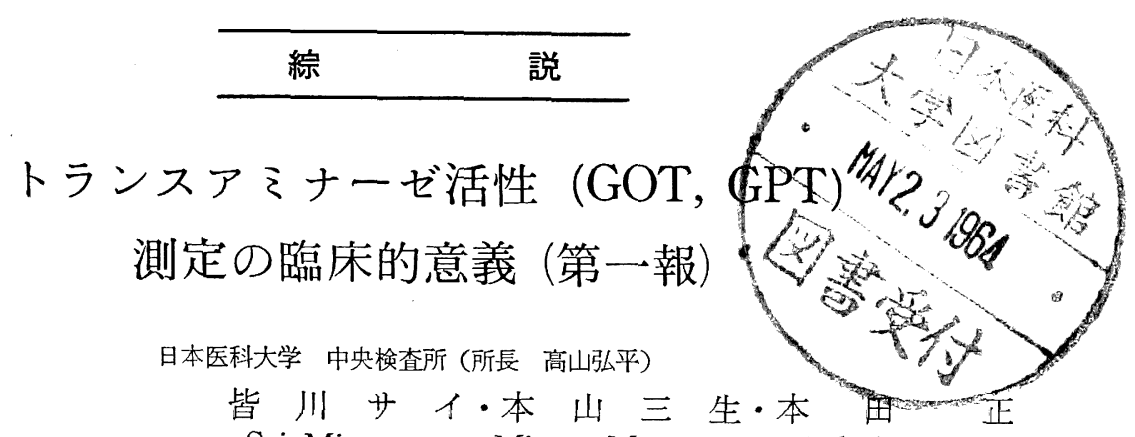

Sai Minagawa Mitsuo Motoyama Tadashi Honda 外山道司・渡辺肇子・高遠祥江 Michiji Toyama Keiko Watanabe Sachie Takato 岡田寿美子・大森幸子・高椋卯吉 Sumiko Okada Sachiko Omori Ukichi Takamuku

1954 年 $\mathrm{LaDue}^{1)}$ 等は心筇梗塞患者血清中「グル タミン酸オキザロ醋酸トランスアミナーゼ」活性 (SGOT)，の著明な上昇を認め，更飞翌 1955 年に同じく S-GOT が急性肝炎患者血清中に上昇寸る事を発見 ${ }^{2)}$, 1956年飞致血清「グルタミン酸焦性萄葡酸トランスア ミナーゼ」活性值 $(\mathrm{SGPT})^{3)}$ \&急性肝炎血清中に上舁 する事を報告し診断的意義を認めた。以来両醉素は 肝, 心疾患時飞測定され診断, 治療効果判定に不可 欠の検査となつて一般的に利用されると至つた。此の 醭素の測定法に就ては古くは Green のWarburg 検压 法 $^{4}$ 汇よる方法, Awapara ${ }^{536)}$ の Paper Chromatography飞よる方法 Wroblewski-Karmen 法 $^{2{ }^{27}}$, Cabaud 法 $^{63}$ 等があるが一般医家による日常検査法としては現 在 Reitman-Frankel 法 $^{8)}$, Sigma- Frankel 法が手技 子簡単で比較的確実な測定值が得られるので一般に行 はれて居る。最近では血清「トランスアミナーゼ」の みならず更と肝生検による組織内酵素活性值, 胆汁, 尿中, 血球中脊璡液中等の醳素活性も測定され論ぜら れると至つた。

GOT は人体内では心㖪筋肉飞最も多く含まれ, 次 いで肝藏, 骨格筋, 腎藏, 脾藏, 脺蔵飞比較的大量飞 存在する ${ }^{10)}$ 。GPT も広篹囲飞存在するが GOT と比 較すると旰に多く含まれ他の臟器には少い3。一般飞 SGOT活性の著明な変化は心筋, 朋細胞障害に伴つて 見られ, かかる障害程度の大体の指標たり得るものと 思はれている ${ }^{211)}$ 。人体各種藏器組織中の GOT, GP $\mathrm{T}$ 活性は婊 1 亿示す通りである。GPT は常に GOT より小さいが両者の割合の上より云へば心筋, 骨格筋
表 1 Comparison of Glutamic Oxalacetic Transaminase and Glutamic Pyruvic Transaminase In Normal Adult Tissue Homogenates.

\begin{tabular}{l|r|r}
\hline & GOT & GPT \\
\hline \multicolumn{2}{|c|}{ Tissue units/gm. wet tissue } \\
\hline Heart & 156,000 & 7,100 \\
Liver & 142,000 & 44,000 \\
Skeletal muscle & 99,000 & 4,800 \\
Kidney & 91,000 & 19,000 \\
Pancreas & 28,000 & 2,000 \\
Spleen & 14,000 & 1,200 \\
Lung & 10,000 & 700 \\
Serum & 20 & 16 \\
\hline
\end{tabular}

(F. Wroblewski and J.S. LaDue)

飞比較して肝臓内 GPT 浸度は GOT 濃度よりも比較 的大である。此の所見忹急性肝炎時の SGPT が SG OT 飞比べて肝細胞障害のより良き指標となる理由と 考学られて居る。逆に GPT は心筋肉では低いので心 笳壊死を起こしても SGPT はSGOTに比べて極めて 軽度又は不鮮明な増加を示すとすぎない゙。Chinsky， Sherry, Wroblewski, LaDue 等 ${ }^{12)}$ は SGOT, の正常 範囲は 5〜40 (A.V. 22上7) SGPT の正常筈囲は 5 $\sim 30$ units/ml (A.V. 16 169 ) で GPT は GOT より 幾分低い。GOTとGPT の比は 1.25〜1.0 が正常で あると述べている。

検体の取扱い法に就ては Karmen 等 ${ }^{6}$ は血清を 0 $\sim 5{ }^{\circ} \mathrm{C}$ に眝藏すれば 2 週間たつても「トランスアミナ 一ゼ」活性に何等著しい変化を来たさないが煮沸すれ 
$-2-(2)$

ば，その活性を破壊すると云ひ，藏器，組織，尿， 胆汁, 煘迹液, 腹水等の取扱ひと関しては Dearing ${ }^{11)}$, Fleisher ${ }^{13)}$, Brenner, Gilbert 皆川(47)等飞より研究さ れて居る。最近 Transaminase の測定は一般検査の中 ととり入れられて利用されて居るので私達は此処に臨 床的意義の概略の説明と簡単な文献的考察を行つてみ た。

\section{急性肝炎, 慢性肝咨:}

急性矣㭧の早期飞於て GPT 活性が GOT 活性より も大きくて，乙かも肝臟毒に暴露された事がないと云 ふ時には先ず急性肝炎が診断される。Sommerville, Fleisher 飞上れば患者の約半数は GOTよりも GPT 值が高い。De Rhitis ${ }^{15)}$ と上れば血清 Transaminase 值は急性伝染性肝炎では常に GOT, GPT の比が逆転 されて居る。Chinsky ${ }^{12)}$, Wroblewski ${ }^{16)}$ は GPT は 急性肝炎患者では大低のもので GOT より大であると 述べている。Pryse-Devies ${ }^{17)}$, Wilkinson は黄犆発生 の3 日以内では GOT の方が高いが次いで GOT が GPT 活性上り急速に減少すると云ふ。伝染性或は急
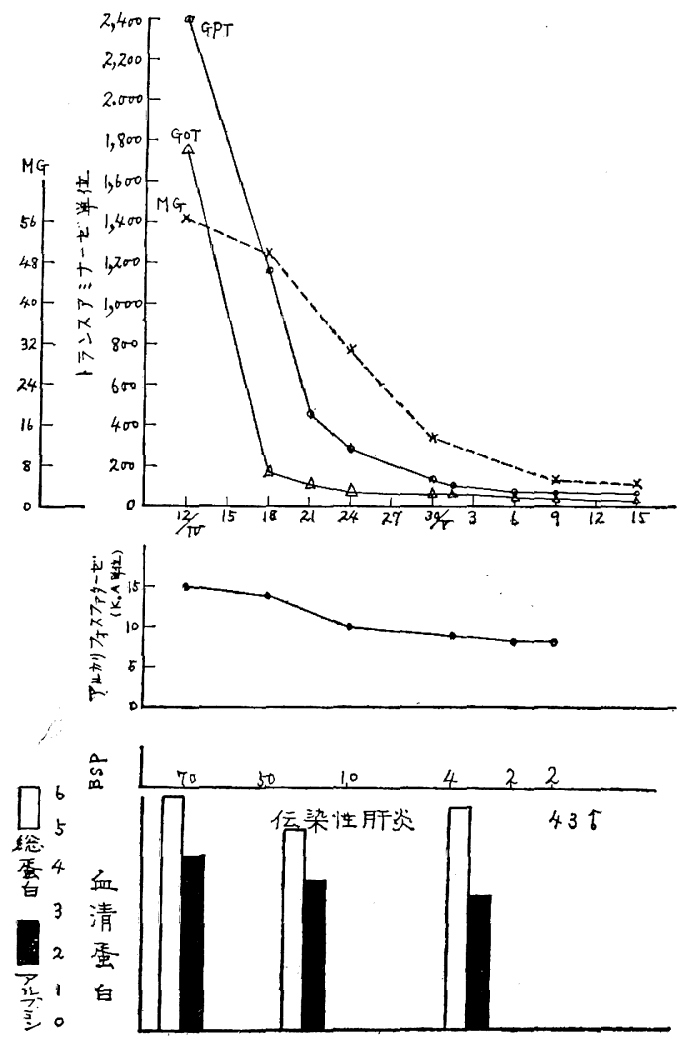

図 1
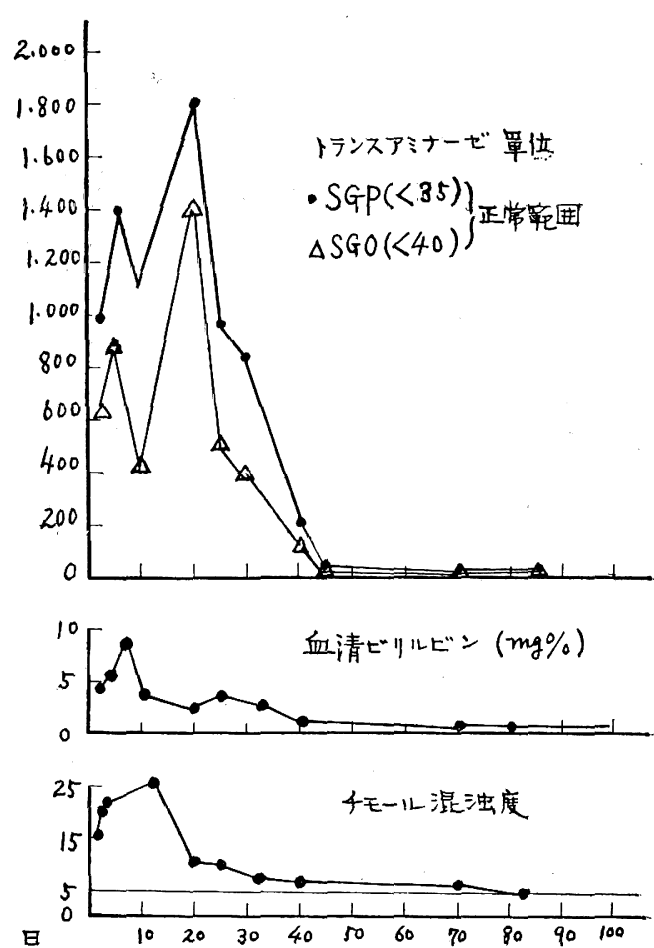

図 2 伝染性肝炎 20 才。

性肝炎飞於て SGOT 怔正常值の 10 倍 40 倍洎增加 する ${ }^{18(2) 19) 20) 21) 22) 。}$

Wroblewski とよれば伝染性肝炎思者の SGOT は その peak 飞於て 400〜2500 単位のものが多い ${ }^{10) 。 ~}$

急性肝細胞障害による患者の SGOT は一般飞閉塞 黄疽に見られるそれの数倍に達する2)。図 1 , 図 2 は 伝染性肝炎患者飞於て見られた検査所見と SGOT の 変化の経過を示した例である。此の䁇者は当初 BSP, TTT, Bilirubin 值が正常なるにもかかからず既飞 SGOT 活性は上昇を示して居た事は注目すべきであ ろう。

血清肝炎に於ける検査所見，臨床所見の経過は伝染 性肝炎に於けるものと同様である。SGOT 亿対する作 用子伝染性肝炎飞於けると同様である事図 3-A 亿示 寸通りである。伝染性或は血清肝炎江於ては血清「卜 ランスアそナーゼ」は臨床病日第一週の間は非常に高 值である。次いで7日以后10日迄急速低くなる。 それ以后「トランスアミナーゼ」が正常值にか党るま で更に一週〜四週の間 50 150 単位の異常值をつつけ $3^{23)}$ 。

ビールス性肝炎の SGOT の上昇は其の笑患の前鴚 期中飞始末り患者が発熱不快感, 食䓡不振, 嘔気, 肝 

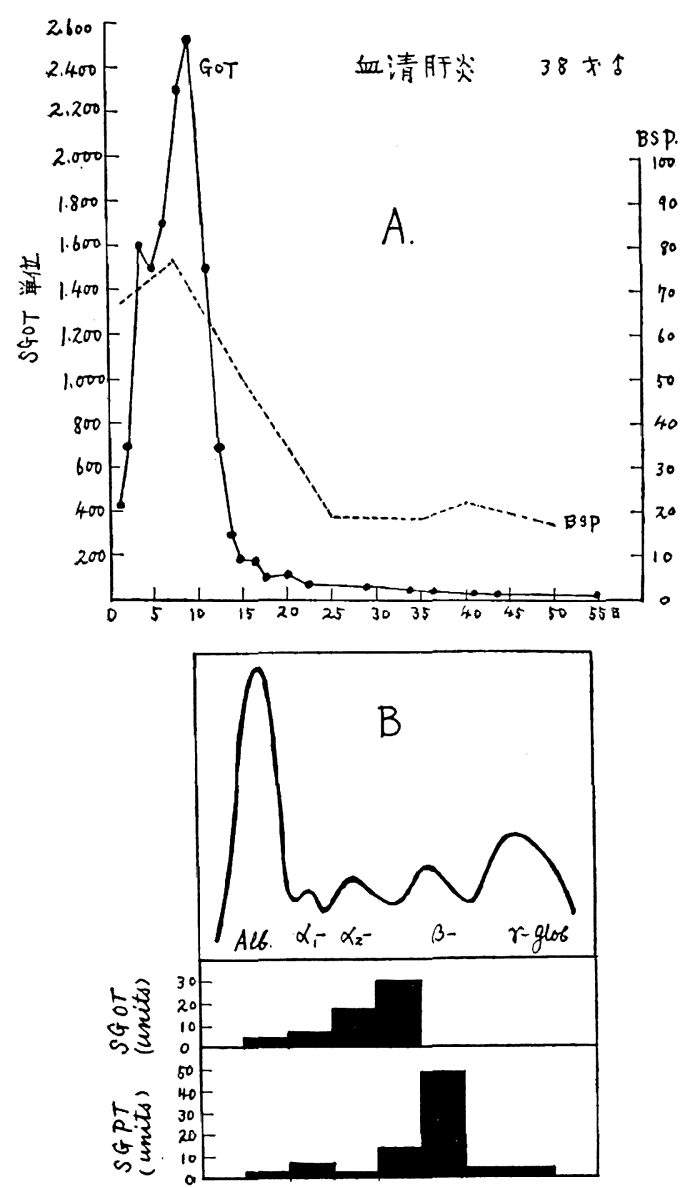

図 3 质染性肝炎に於ける, SGPT, SGOT 電気泳動可動性

腫等の臨床所見の上で最も悪く見光た時 SGOT 活性 も亦最高澾する。自覚的, 他覚的所見の改良と共に SGOT は下降して正常值にもどる ${ }^{18)}$ 。伝染性肝炎, 血清肝炎例で時飞経過が長引きしつように異常高值が つづく事がある ${ }^{12243) 。 ~}$

肝疾患に於ける SGOT 活性值は一般に用ひられて 居る肝機能検査成績と平行もしないし相関々倸にもな い。SGOT 活性值の上昇は肝機能ではなくて肝細胞

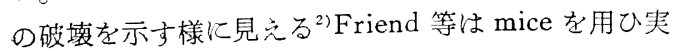
験的に「ビールス」性肝炎の血清「トランスアミナー ゼ」を研究した。彼等は感染動物のすべてに於て「ト ランスアミナーゼ」活性值が著しく上昇するのを観察 し此の際「トランスアミナーゼ」活性值の上昇「ビー ルス」接種量, 血液「ビールス」力価と肝裁の壊死の 程度との間関連がある事を明かてしている。Wroblewski，La Due ${ }^{2222)}$ に上れば伝染性肝炎の小数例で
「トランスアミナーゼ」值が一般肝機能検查が復旧寸 る前に正常にもどつた事に注目して居るが血清「トラ ンスアミナーゼ」活性の正常化の状態を他の肝機能検 查のそれと比較して見ると一般に尿中「ビリルビン」 の消失よりは遅れるが血清黄疽指数や BSP 試験の回 復よりは先行寸る ${ }^{311}$ 。原田 ${ }^{48}$ 络肝炎初期に「トランス アミナーゼ」は著明急激に上昇し,300単位以上になる 事が多く,しかもMG, BSP 停滞, 血清鉄等に先だつ て速か、下降正常化する事は他の疾患と明か儿鑑別出 来るものであり，日を追つて「トランスアミナーゼ」 を測定する事により之を容易に搒断し得るとしてい る。現在の所, 他の肝機能検查の内血清「トランスア ミナーゼ」值と相関を有するものなく之に代り得る検 查法はない。Chinsky は疾患早期の壊死は疑ひもなく 「トランスァミナーゼ」上昇に笴与しているが併しそ れに引続いて持続する血清「トランスアミナーゼ」值 の上昇は分泌機構の欠宿に関係して居るものであるう と云ている233。

伝染性単核症に於て一般に SGOT 活性は正常であ る。併し更に肝炎を併発すると SGOT の上昇を来 $す^{20)}$ 。伝染性単核症に伴つた肝炎の重篤度はSGOT, の peak の高さと関係ある様汇見光る ${ }^{18)}$ 。図4 は急性

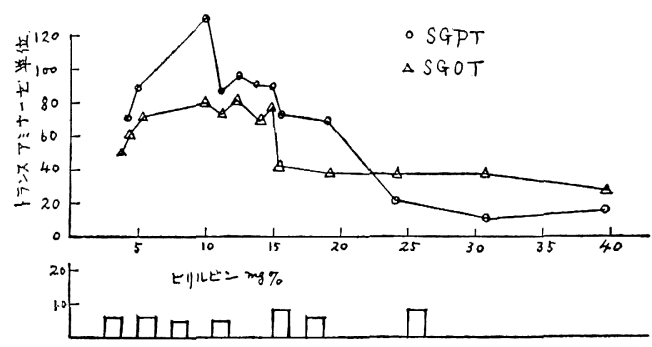

図 4 伝染性単核症に伴つた肝炎の トランスフミナーゼ 30 才。

伝染性単核症に伴つた肝炎患者に見られた SGOT 活 性の変化の経過である。かかる患者の多くは 4 週間以 上にわたり 80 300 単位のSGOT 上昇を示す。

伝染性肝炎のSGOT は急速に上昇して後回復期に 入り正常值に向つて次第に減少するものであるが感染 或は合併症が肝炎経過中に持こるならば此の附加的 Stress は肝炎流劉し二次的に SGOT 活性の一首の 上昇を来寸図 5 。早すぎた退院等による「ぶりかえし」 も亦 SGOT の二次的增加を伴ふ。SGOT 活性加仲々 正常筙囲にもどれ娃は䝢性肝炎光の発展か, 又は伝 染性肝炎后肝硬变症を暗示して居る。伝染性肝炎の経 過に於ける SGOT の一連の変化は特徵ある pattern 


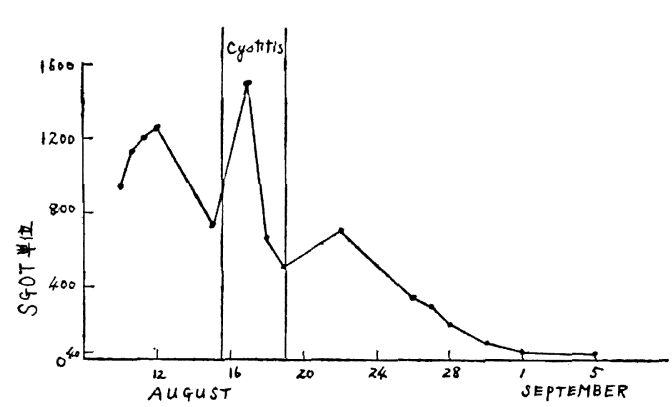

図 5 急性肝炎患者に尿路感染老伴つた 場合の SGOT 变化 72 才

在示して居る。此の pattern から逸脱する事は合併症 のある事又は病気の「ぷか党し或は伝染性肝炎の潜 在存続或は慢性化を暗示するものである ${ }^{10)}$ 。肝炎の前 駆期に見られるSGOT の増加や，急性肝炎の無症状 型又は亜黄疽型の SGOT の变化は此等の病気の診断 に役立つものである ${ }^{10)}$ 。

臨床的に一見急性肝炎が完全に治撚したかの様に見 えても SGOT, SGPT 活性の完全な正常化を見ず或 は長期にわたり活性值の異常を見ることがかなりあ る ${ }^{24)}$ 。Mosley ${ }^{25)}$ によれば伝染源を同じくして集団発 生した伝染性肝炎群に於て 3 週間後患者の 58\% は異 常 SGOT を示し, 100\% の患者が異常 SGPT を示 した。同じ患者達に於て6ケ月目には何等臨床的に異 常老伴は欢にかかわらず $20 \%$ の者が異常 SGOT, S GPT 示していたと云ふ。一般に GOT, GPT の测 定は急性肝炎の彰断に最大の価值むるものであるが急 性肝炎に引続いて血清酵素活性が仲々正常にもどらぬ 事，又は波状をなして增減をくりかえし，しつように 異常值を続ける事がある。Fleisher ${ }^{13)}$ によればかかる

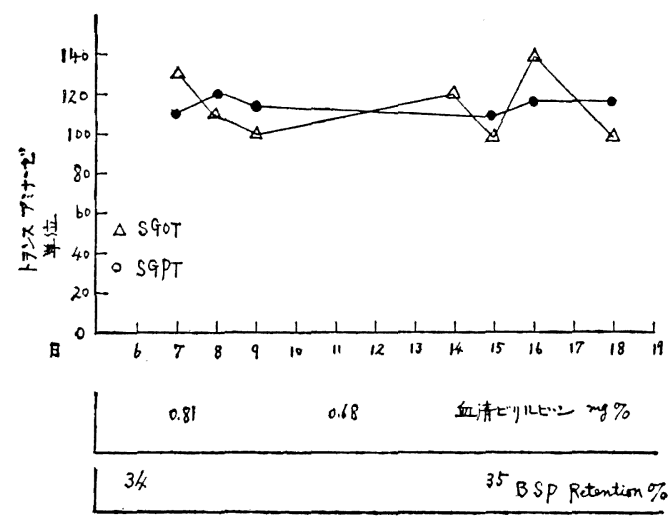

図 6 慢性肝炎 61 才。
時は慢性肝炎后肝硬変症が扣こりつつある可能性を考 え憼戒すべきであるとしている図 6。Molander は肝 硬変の他の型から肝炎后肝硬変, 慢性肝炎を鑑別する には「トランスアミナーゼ」の測定が最も価值むるも のだと云つている。又慢性肝炎への発展は異常SGOT の持続により又 SGOT>SGPT で示され, 肝炎経過 中に於ける SGOT の量的変化は旧来の肝機能検査法 よりもより良く臨床所見を反映する ${ }^{218) 201 。 ~}$

\section{肝硬変症 :}

肝硬変症の代償期の SGOT は正常であるが代償不 全を来したり, 活性期にあるときは黄疽, 腹水, 浄腫 と共に SGOT は 40 単位から 300 単位ぐらいの種々 の程度の SGOT 上昇を伴ひ正常值以上の值で日日動 摇している ${ }^{10)}$ 。一般に肝硬変症では GOT>GPT の 事が多い13123)。GOT はかなり上昇しても GPT は正 常範围内の事が多い。肝硬変症で GOT, GPT が 300 単位以上となつた時は流行性肝炎の併発を考へなけれ ばならない226!。肝硬変症の上に急性肝炎が併発する と肝炎に対してのべたと同じ様な特徴ある SGOT の 変化を示す。図 7 は急性肝炎を合併した肝硬変患者の

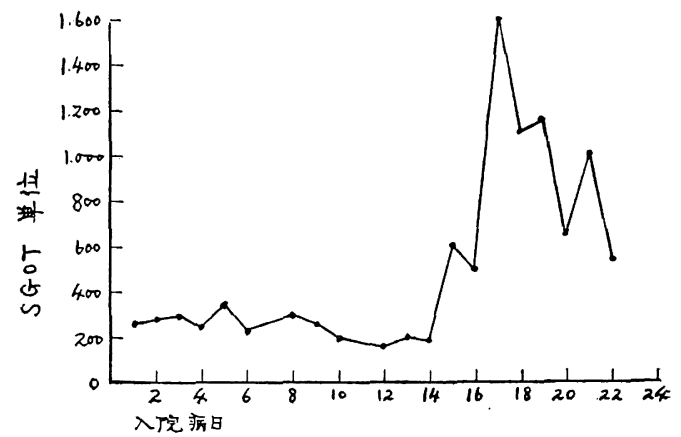

図 7 代㒔不全 Laennec 肝硬变症に急性肝炎 を併発せる場合 73 才。

SGOTの変化を示したものである。急性肝炎を併発し た肝硬変症では急性肝炎による特徵的な著しいSGOT SGPTの変化を示す。此の際には肝硬変による酵素值 の上昇の上に肝炎のそれが附加された像を示してい る ${ }^{2)} 。$ 此の事実は肝硬変症が突然肝代償不全を来した のか, 肝硬変思者に急性肝炎が併発したのかどうかを 決定するためには「トランスアミナーゼ」活性の測定 が行はれるべきであると云ふ事を示するのである ${ }^{18)}$ Mason によれば活動期の, 又は代償不全を来した Laennec 肝硬変症の SGOT は 50 250 单位の筑囲 で上下する2012)。Wroblewski によれば肝硬変症では 全例 SGOT 活性は SGPT 活性より大である。図 8 


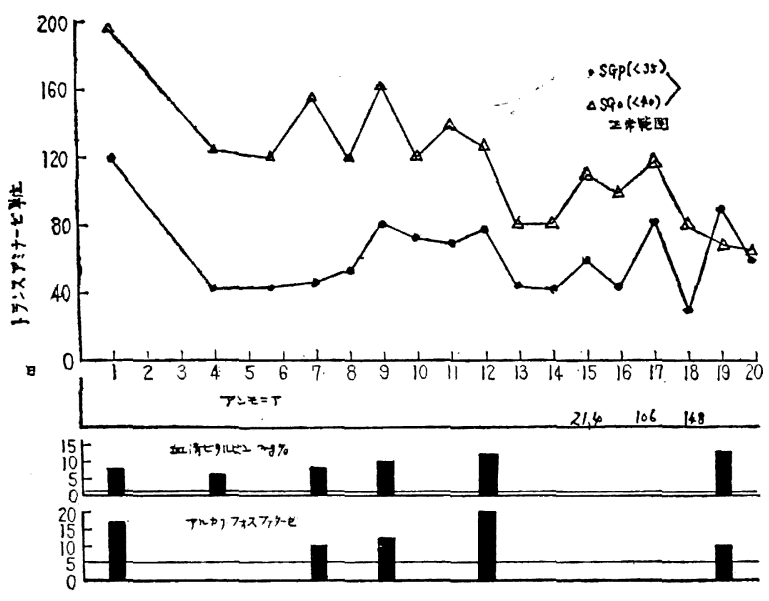

図 8 壊死後肝硬変 51 才 $\hat{o}$

は壊死后性肝硬変症の一例に於ける SGOT, SGPT の 変化と他の検査所見を示している。此の患者演淔あ り肝脾腫, 腹水, 浮腫を有していたものである゙”。一 般的に云へば「ビールス」性肝炎と反対に肝硬変症で 「トランスアミナーゼ」值が上昇するときには GOT は GPTより高值であるが Fleisher によれば代償性 Laennec 肝硬変症㭧者について, GOTに関して, そ の $12.5 \%$ だけが正常範囲内に GPT に関しては 50\% が正常範囲の値を示した。代償不全の肝硬変をもつた 患者の血清 GOT 活性は代償性肝硬変をもつた患者の それよりも明かに高い。一方 GPT 活性は代償不全の 発展により著明な変化は見られない。

代償不全の Laennec 肝硬変で肝性昏睡を伴つた思 者の SGOT, SGPT の平均値は代償不全ではあるが

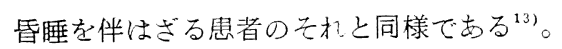

慢性肝疾患に於ては恐らく一方にては肝細胞の再生 を伴ひつつ, 他方にては肝細胞の一定数の死が持続し ているものと思はれる。門脉性や胆汁性肝硬変を有寸 る患者に見られる「トランスアミナーゼ」の軽度の上 昇は肝史質の此の持続的破壊過程を反映して居るもの であろう (Molander) ${ }^{27) 。 ~}$

肝硬変症では肝組織中 GOT 活性は対照群よりも 増加しているが GPT 活性值は対照群より明かに少 $W^{13}$ 。肝組織中の酵素活性の変化は再生結節の存在に 関係しているかもしれぬ (Sommerville) ${ }^{13)}$ 。組織中の 䤏素活性之血清中の醣素活性の変化の間に何等かの関 係を見つけようと云方試みが行はれて居る。併し今の 所多くの不明の因子か力加る酵素の産生, 遊離之排出 との関係をControl して扣る様である。胆汁性肝硬変 症の患者に於ける醉素活性值の上昇は代償不全を招こ
した Laennec 型肝硬変症の患者の值よりも高 い。之れに対する理由は十分に明かではないが此 の疾患にて起る部分的の胆汁閉塞によるものと考 へる人もいる ${ }^{27) 。}$

「トランスアミナーゼ」測定は肝硬変の他の型 から肝炎后肝硬変, 慢性肝炎を鑑別する時に最も 価值がある図 8 。此の群の SGOT, SGPT, の平 均值は他の肝硬変群の何れよりる著しく高い ${ }^{13)}$ 。 即ち䏅死后性肝硬変, 胆汁性肝硬変, 阴脉性肝硬 変の順で SGPT, SGOT : 活性值が低くなる傾 向にある ${ }^{13) 23) 27 。 ~}$

肝硬変症の組織所見との関係について生検或は 剖検にて活動性炎症と壊死の形跡のあつた患者達 に於ては「トランスアミナーゼ」值が高まつて居た。 又一方「トランスアミナーゼ」の上昇して居た患者は すべて肝機能検査で異常值を有していた。Chinskyは 正常血清「トランスアミナーゼ」值を有する肝硬変患 者三例の組織学的観察を行ひ與味ある報告を行つて居 る。患者の一名は肝性昏睡にて死亡したが剖見所見は 急性壊死の形跡なく進行した肝硬変のみであつた。他 の二例は強い黄疽, 著しい脂肪滲潤をもつた肝硬変で あつたが缺死の部分は見られなかつた。かかる例は肝 疾患に於ける血清「トランスアミナーゼ」活性が活動 性細胞壊死と密接に相関があると云ふ見解を支持する ものである ${ }^{23)}$ ○Dunn ${ }^{28)}$, Amelung は血中に增加せる 醭素活性は急速に組織液に移行した後徐々に破壊か, 不活性化されると述べて扣り, 鹿島 ${ }^{29}$ は肝硬変患者の 腹水及び「ネフローゼ」患者の腹水に GOT, GPT 活 性を認めている。

\section{閉塞性黄疽 :}

閉塞性黄疽に於ては SGOTは300 単位を越克ず比 較的安定して居るか或は機械的開塞が除かれる迄ゆつ くりと増加する゙”。此の様な胆道閉塞時「トランスア ミナーゼ」活性值の所見によつて伝染性又は血清黄疽 の SGOT が疾病の早期に連続的に測ら机るならば之 等を閉塞性黄疽から鑑別する事が出来る ${ }^{21}$ 。Wroble$\mathrm{wski}^{3)}$ は総胆管結石で 2 日，6日，12 日間黄疽を続 けて居た 3 名の患者の「トランスアミナーゼ」を測定 報告して居る。その SGPT 活性は $279,242,164$ 単 位であつたが術后 2 週間以内に何れも正常值にもどつ た。Masonに上れば肝外性又は肝内性胆道閉塞に於て

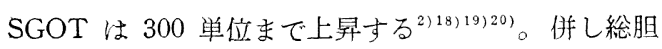
管の閉塞が除かれると 7 日から 14 日の間に SGOT は正常值に下降すると云ぶ2。 
$-6-(6)$

胆石症に上る二次的肝外閉塞性黄瘨患者 5 例につい て見るに内 3 例は GOT 上昇, 4名は GPT 上昇を示し ていた。GOTよりGPT はより強く増加する傾向にあ つたが此の相違は急性肝炎に於けるほど顕著ではなか つた。(Chinsky) ${ }^{12)}$ Chlorpromozin 黄疽例の大部分で GOTより GPT ば明かに增加を示した ${ }^{13)}$ Thorazin による二次的肝内性閉塞の患者 4 名の「トランスアミ ナーゼ」の観察では肝炎例と同様な pattern を示した がその值は肝炎におけるほど著しく高いものはなかつ $た^{12)}$ 。肝外性閉塞に於ては閉塞の本体の如何にかかわ らずGOT, GPT は一様に增加していた。肝外性閉塞 性黄宜患者の約 $1 / 3$ 例では GPT は GOTより大であ つた (Fleisher) ${ }^{13)}$ Wroblewski は閉塞性黄瘨で GPT 活性の著しい上昇がある事を報告しているが之れを以 て肝硬変の患者又は肝に於ける腫㾨転移をもつた患者 を胆石，癌又は他の原因による閉塞性黄疽から鑑別す る事は出来ないと云つている21。

総胆管狭穾或は膵炎時の「トランスアミナーゼ」值 は総胆管の結石性閉塞に於けるより高い值を示す傾き がある。肝外性閉塞性黄瘨に於て GOT 活性も GPT 活性も閉塞の原因を鑑別する事に関しては価值はな い。又閉塞性黄疽を伴つた患者に於て黄县の期間と 「トランスアミナーゼ」の大きさとの間には相関を欠 いて和る ${ }^{13)}$ 。(hinsky ${ }^{23)}$ によれば閉塞性黄瘨例は総胆 管結石, クロールプロマヂン黄疽, 膵頭部痹によるも のが多い。「トランスアミナーゼ」増加は長期にわた る閉塞性黄瘨でだけ観察された。閉塞性黄疽に於ける GOT 值は肝硬変に於けるものより一般に著しく高值 である。GOT, GPT 活性値の増加は血清 Bilirubin 值が $10 \mathrm{mg} \%$ 位に至る迄は或る程度比例すると云ふ 報告もある (Fleisher)。溸次上昇する血清 Bilirubin 值と共にトランスアミナーゼ」值が持続的に増加する ときは閉塞性黄疽が考へられる。之れに反し急速に変 化する醉素活性は急性肝炎の可能性を考へさせる

急性膵炎に伴ふS SGOT の上昇は一時的の総胆管閉 塞によるものとして説明されて居るが胆道閉塞を伴は ない膵瀻壊死が SGOT 上昇にみちびき得るや否やは 明かでない(18)。肝炎群と反対に閉塞性黄瘨贯者は大部 分「トランスァミナーゼ」值 200 単位以下の值であつ た。閉塞性黄㨁患者の一例で 600 単位に及ぶ高值を有 するものがあつたが，てれは心筋梗塞併発の疑ひ濃厚 な例であつだ2゙

鹿島 ${ }^{29}$ は SGPT, SGOT が 101 単位以上のものは 一応肝胆道疾患を考へるが SGOT が 501 単位以上の
ものは全例肝実質性疾患であつた。

SGOT が 101 500 単位の中には肝㬰質性のものと 胆道性のものとが略同率に存している。

SGOT 1,500 単位以上, SGOT 1,001 単位以上の ものは急性若しくは亜急性肝炎として良い。SGPTが 1,000 単位以下の場合には此れのみを以てしては急 性, 慢性肝実性疾患の区別はもずかしいとしている。

非常に高い「トランスアミナーゼ」値 (400 単位以 上）は閉塞よりも細胞壊死を合併して居るものであ る。

閉塞性黄疽に認められた「トランスアミナーゼ」上 昇は肝の正常分泌機構の障害で説明され得るけれども 閉塞性黄疽患者にて正常「トランスアミナーゼ」值を 有するものがある事，「トランスアミナーゼ」值上昇 と Bilirubin 上昇の間に相関々係を欠いて招る事は此 の他の因子の存在する事党示するものである

閉塞性黄疽で執拗に SGOT 活性が上昇して下らぬ もの, 閉塞性黄疽に肝炎が併発したものでは多くは予 后不良であつだ2。

Mason ${ }^{18)}$ は犬を用ひ総胆管の実験的閉塞を行つた が SGOT 活性の著しい上昇を来した。それは胆管閉 塞の除去により一週間以内に正常值にか党つている。 ChinskyはRATを用ひ釉胆管結禁が「トランスアる ナーゼ」值に如何に影響するか其の効果を研究した図 9 。対照の SGOT, SGPT 活性は全観察期間中著しい

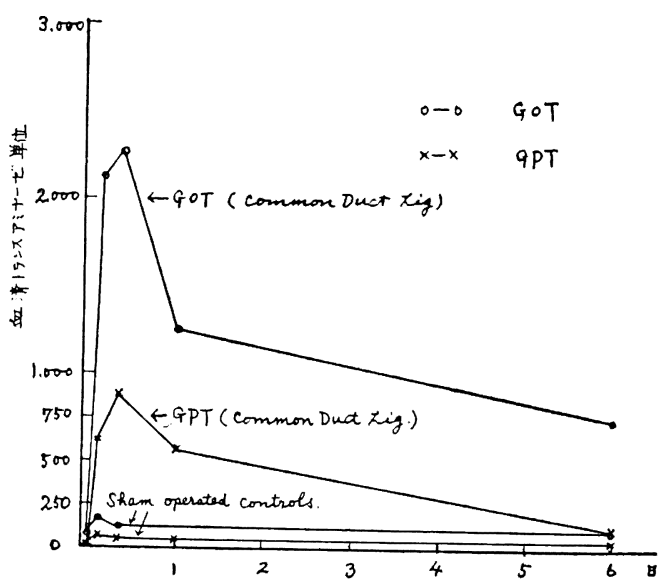

図 9 正常 Rats, の血清トランスフミナーゼ に及ぼす総胆管結紮の影艟

変化はなかつた。之れに反し総胆管を結紫せる RAT は著しい「ランスアミナーゼ」活性の上昇を伴つた。 GOT は GPT より多く増加し結柴後 6 時間の peak の時には GOT 2,300 単位に達した。次いで閉塞の持 
続して居るにもかかわらす减少し始め術後 6 日目には GPT は殆んど正常值に達したが GOT は尚ほ可なり 上昇しているのを認めた。武内神は犬を用ひ胆道閉塞 実験を行ひ GOT 150 200, GPT 350 単位ぐらいま での上昇を認め活性值上昇あるものに続発性二次性 肝細胞障害を来していた事を発見した。即ち胆汁は 「トランスアミナーゼ」排出路の一つであると考へら れるので，その排出障害は活性値上昇の一因と思はれ る。

Wroblewski ${ }^{10)}$ によれば肝外胆道閉塞性黄誼では大 凡 SGOT 活性は 100 300 単位のものである図10。

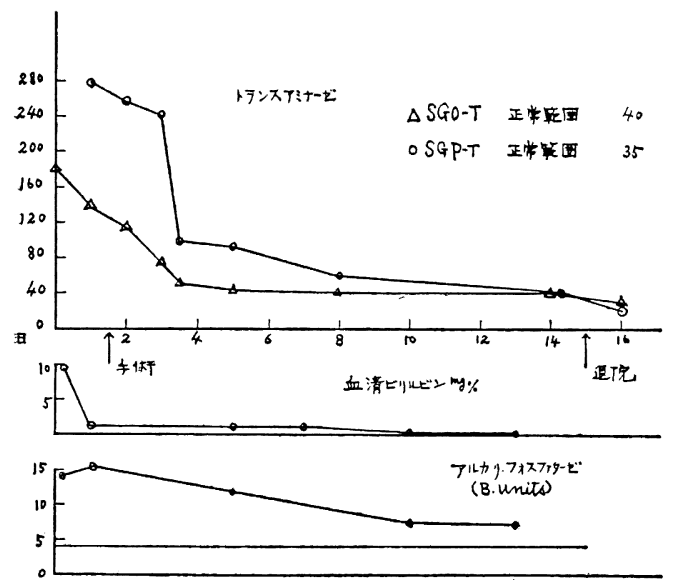

図 10 総胆管結石

此の際「トランスアミナーゼ」と「アルカリフオスフ アターゼ」との関係については図10亿示す様に GOT
は胆道閉塞除去と共に急速正常值にかるるが「アル カリ, フオスファターゼ」は更に数日間長く上昇して 居るものである。

手術時, 手術后又は肝硬変, 閉塞性黄疽に於ては血 清 GPT の增減はGOT に較べると遅れて㧍こる。之 の所見から「トランスアミナーゼ」が血清中へ解放, 遊髉され, 又血清中から排除される事に関して此の二 つの醉素の間には相異があるものと考光られる

一方急性肝炎患者等の血清を㴔紙泳動すると血清蛋 白分画上 SGOT は主として $\alpha_{2}$, SGPT は主として

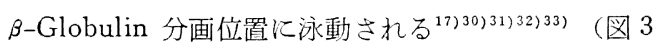
B)。又 $\mathrm{Green}^{4}$ は GOT の分子量は 60,000 GPT の それは 180,000 と記載している。

臨床的にも SGOT, SGPT が高い程尿中の GOT GPT 活性值も高い傾向がある ${ }^{17334)}$ 。又血清中の GOT GPTの状態の如何にかかわらず尿中ではGOT $>$ GPT の場合が圧倒的飞多い29)。

Dearing, Fleisher ${ }^{14)}$ 等により手術時に得られた肝 組織の GOT, GPT の測定が行はれている。

肝組織中 GOT 活性は肝硬変にて最も高く閉塞性黄 疽を有するものが之れにつぎ対照より高まつていた。 反対に GPT 活性は肝硬変にて最も低く, 閉塞性黄瘨 は之れについで対照例より低值であつた。此等二つの 醉素が互に反対の方向湾化する理由は明白でないが かかる変化は再生した肝結節の存在と何等かの関係が あるものと考へる事が出来る。

本論文は高山中央検査所長の指導ならびに校閲至うけた。 